\title{
Parry-Romberg syndrome: uncommon but interesting
}

\author{
Deepshikha Trisal, Naveen Kumar, Gaurav Dembla, Deepak Sundriyal
}

Department of Medicine, PGIMER \& Dr Ram Manohar Lohia Hospital, New Delhi, India

\section{Correspondence to} Dr Naveen Kumar, docnaveen2605@yahoo.co.in

Accepted 8 September 2014

CrossMark

To cite: Trisal $D$, Kumar $N$ Dembla G, et al. BMJ Case Rep Published online: [please include Day Month Yearl doi:10.1136/bcr-2013201969

\section{DESCRIPTION}

A 12-year-old boy presented to us with a 3-year history of gradual onset progressive atrophy of the left side of the face (figure 1). There was no history of headache, facial pain, seizure, visual symptom, head trauma or family history. On examination, there was wasting of the entire left half of the face. A central ridge on the forehead was present, with left side underdeveloped compared with right side. The left cheek, left side of nose, zygomatic areas, left side of lips and jaw were atrophic compared with right side. Left side enophthalmos and associated alopecia on left half of head were also present. There was no hyperpigmentation, with normal ocular movements and facial nerve examination. In routine laboratory investigations, ultrasonography of the abdomen and autoimmune profiles were normal. Skin biopsy from the atrophic area of the left cheek showed atrophy of epidermis and dermis with loss of fat in subcutaneous tissue. Areas of localised fibrosis were present.

Parry-Romberg syndrome (PRS) or idiopathic progressive hemifacial atrophy is a rare condition characterised by atrophy of the skin, subcutaneous tissue, muscles, cartilage and bone on one half of the face. ${ }^{1}$ The aetiology of this condition is unknown; possible factors having a role are trauma, viral infection, genetic factors, autoimmunity, endocrine disturbances, peripheral trigeminal neuritis, increase of cervical sympathetic nerve activity resulting in facial atrophy and cerebral disturbance of fat metabolism. It usually begins in the first two decades of life, with gradual progression over several years, and ultimately ceases at any stage, with no spontaneous recovery. ${ }^{1}$ The condition has overlapping features with 'en coup de sabre', a type of linear scleroderma affecting the head. However, recent studies suggest that PRS is a clinical subtype of linear scleroderma. ${ }^{2}$ Findings favouring linear scleroderma are positive antinuclear antibody, sparing of underlying muscle or bone, no involvement of tongue and nerve conduction slowing in affected areas. Other differential diagnoses are hemifacial microsomia (first and second branchial arch syndrome), facial paralysis-associated atrophy, unilateral partial lipodystrophy (Barraquer-Simons syndrome) and traumatic fat necrosis.

Apart from skin abnormalities, PRS can have articular, autoimmune, neurological, ocular and dental abnormalities. ${ }^{1}$ It can cause atrophy of internal organs (kidney, adrenal glands, ovary) and sometimes even of an entire half of the body. Common complications are: severe headache, migraine, trigeminal neuritis, facial paraesthesia

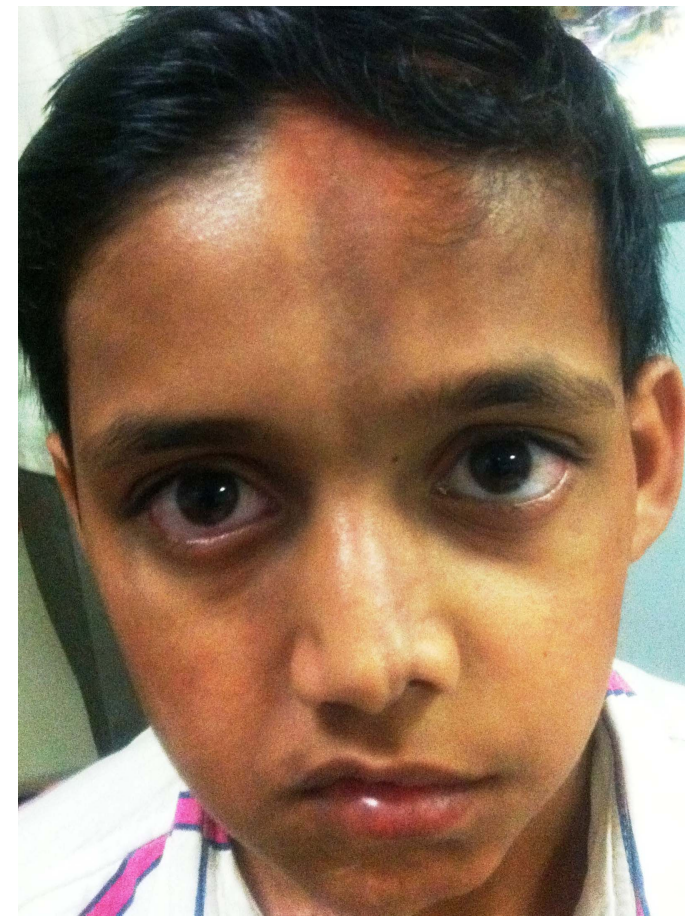

Figure 1 Parry-Romberg syndrome: atrophied left half of face.

and epilepsy. After stabilisation of disease, deformity can be corrected by plastic surgery with grafting of autogenous fat. We established the diagnosis of PRS based on the clinical picture and biopsy. Since the lesion was stable for the past 8 months and there were no extra-cutaneous manifestations, we referred the patient to the plastic surgery department for corrective intervention.

\section{Learning points}

- Parry-Romberg syndrome (PRS) is a degenerative condition of unknown aetiologies, characterised by a slow, progressive unilateral atrophy of facial tissues (muscles, bones and skin).

- It is important to differentiate PRS from localised scleroderma, as the treatment used in the latter has no role in PRS.

- It is a self-limiting condition with no cure. Surgical intervention to correct deformity is recommended when the illness stops its progression. 
Contributors DT and NK contributed to diagnosis of patient, concept of paper, acquisition of data, drafting, revision and final approval of the article. GD contributed to diagnosis of patient, concept of paper, acquisition of data, revision and final approval of the article. DS contributed to diagnosis of patient, concept of paper, drafting, revision and final approval of the article.

Competing interests None.

Patient consent Obtained.
Provenance and peer review Not commissioned; externally peer reviewed.

\section{REFERENCES}

1 Stone J. Parry-Romberg syndrome. Pract Neurol 2006;6:185-8.

2 Tollefson MM, Witman PM. En coup de sabre morphea and Parry-Romberg syndrome: a retrospective review of 54 patients. J Am Acad Dermatol 2007;56:257-63.

Copyright 2014 BMJ Publishing Group. All rights reserved. For permission to reuse any of this content visit

http://group.bmj.com/group/rights-licensing/permissions.

BMJ Case Report Fellows may re-use this article for personal use and teaching without any further permission.

Become a Fellow of BMJ Case Reports today and you can:

- Submit as many cases as you like

- Enjoy fast sympathetic peer review and rapid publication of accepted articles

- Access all the published articles

- Re-use any of the published material for personal use and teaching without further permission

For information on Institutional Fellowships contact consortiasales@bmjgroup.com

Visit casereports.bmj.com for more articles like this and to become a Fellow 